Marquette University

e-Publications@Marquette

English Faculty Research and Publications

English, Department of

$1-1-2000$

Fantasy, Trauma, and Gothic Daughters:

Frankenstein as Therapy

Diane Hoeveler

Marquette University, diane.hoeveler@marquette.edu

Published Version. Prism(s): Essays in Romanticism, Vol. 8 (2000): 7-28. (C) 2000 International Conference on Romanticism. Used With Permission. 


\title{
Fantasy, Trauma, and Gothic Daughters: Frankenstein as Therapy
}

\author{
Diane Long Hoeveler
}

rankenstein stands as the center and high point of Mary Shelley's literary career, although it was actually her first extended and completed work. She was only nineteen when she wrote it, and she never again surpassed it in terms of artistry or power of vision. Her conscious grasp of its full implications and revelations is a topic still hotly debated among its critics, but its power resides, I would argue, in its unconscious working out and through the author's own intense sense of victimization, and her increasingly desperate struggle for love and family. The novel functions as a form of therapy for a young woman trying to resolve the consequences of her traumatic birth, troubled childhood, and chaotic courtship. As an extended fantasy, the novel attempts to "act out" the author's own intense ambivalence about her parents, her siblings, and her lover/quasi-husband, Percy Shelley. The work's canonical status, only recently gained, attests to its survival as a precursor for both the SF genre and the gothic romance. As philosophy, metaphysics, proto-Marxian 
political and social allegory, family romance, and pre-Freudian dream-vision, Frankenstein can be read on so many different levels that its polyvalence actually has caused its polymorphously perverse critical reputation. ${ }^{1}$ It is the source as well as the outcome of the many strands of both female and gothic traditions in writing; it is the mother-lode, and yet it is a work-like all of Mary's works-that is obsessed with fathers and daughters, both real and imagined.

Much has been made over the years about the chinese box structure of the novel, with the creature's narrative forming the innermost core of this most elaborately wrapped text. Reading the creature- "his" identity and version of events throughout the work-is the key to understanding Mary's purpose and meaning. But if you will indulge my critical perversions for a moment, consider how the novel changes when we read the creature's tale as a muted and mutated exploration of what it means to be a gothic daughter-traumatized, wounded, and deserted-in a man's world. If we post the claim that at the age of nineteen, Mary Shelley could not yet write openly or self-confidently in her own voice, then I think we can understand why she would have hidden her own rage beneath the trappings of a monstrous amalgam of a character like Frankenstein's creation. Created by the aborted efforts of her absent but famous mother and the bumblings of a loving but flawed father, Mary Shelley could quite readily have identified herself as a monstrous production, motherless and rejected by a cold, self-involved father. ${ }^{2}$ But the creature is not simply or readily seen by us as "female,"- "his" body is certainly coded as diseased, aberrant, and freakish, much in the same manner that the bodies of other women in Mary's corpus are depicted as flawed. A genuine horror of female flesh and childbirth exudes from Mary's works, and we will see that repulsion depicted in all of the major "female" characters-gothic daughters-in Frankenstein-Caroline Beaufort, Elizabeth, Justine, the creature and "his" creator. To be female, Mary not so subtly suggests, is a to be a victim of not only society, but of a monstrous body tied to a cycle of biological decay and death. Her fantasy solution to this trauma is elaborated in the novel, a work that punishes both men and women for their failings to love enough to create an idyllic world for their children. A very infantile desire motivates this text-anger and rage at the betrayal of both parents to sustain the illusory omnipotence that the child feels is her magical birthright. 
We begin our examination not with the creature, which is where we must conclude, but with the three women who stand in archetypal relation to Victor: his mother Caroline, his beloved/adopted sister Elizabeth, and his servant/ scapegoat Justine. These women revolve around Victor like embodied wish-fulfillments, suggesting that he has created them out of, and as an expression of, his own psychic needs. All of these women stand, however, as recognizable stereotypes within the female gothic genre. The suffering mother as a victim is a gothic staple, just as much as the persecuted beloved and the expendable servant. Mary was clearly working within the sentimental and gothic modes throughout this work, but the difference and the power come from her gendered twisting of the central controlling consciousness of the text. If Victor and his creation were women we would recognize them as Emma and her protégé Harriet Smith, or perhaps Jane Eyre and Bertha. I would argue that Victor and his monster-creature are as "feminine" as any of the other "women" in the novel, but we will move to an analysis of Victor/the creature as a gendered construction only after we have examined his three blatantly female avatars.

Let us begin where we must: with the mother. Notice that the mother of all the major characters in the work is presented to us in the most blatantly sentimental manner possible: a gothic daughter grieving for her dead father. An ideological creation, Caroline Beau-fort, beautiful city, is an ideal locus, a remembered nostalgic and utopian construct, a child's memory of the mother's body before the child's birth, before the onset of difference, separation, and otherness. ${ }^{3}$ Caroline bears more than a passing resemblance to Radcliffe's noble but impoverished heroine Ellena (in The Italian). Like Ellena, Caroline seeks to support her only family - this time an improvident father-with her pathetic efforts at plaiting straw. We are told that Caroline "possessed a mind of an uncommon mould; and her courage rose to support her in her adversity" (R 28). She becomes a typical gothic heroine when her father dies in her arms and she finds herself "an orphan and a beggar" (R 28). Note the highly stylized manner in which Caroline, however, is saved from this financial fate worse than death. No sooner does she place her father in his coffin, then she has a father-replacement, M. Frankenstein, her father's contemporary and best friend. The scene in which Caroline wins her man deserves scrutiny: "This last blow overcame her, and she knelt by Beaufort's coffin, weeping bitterly, when my father entered the chamber. 
He came like a protecting spirit to the poor girl, who committed herself to his care" ( $\mathrm{R} 28$ ). What is interesting about the scene of a beautiful young girl weeping at her father's coffin is the manner in which it serves as a sexual lure to another older man, indeed, a man old enough to be Caroline's father himself. Tears have long been the coin of the realm in the sentimental universe, and Caroline has them in abundant supply. Abject sorrow, weakness, helplessness and hopelessness, complete dependence-these are the traits that ideologically code a woman as both sexual and attractive in the eyes of the discerning M. Frankenstein and his culture.

As readers we experience this scene not simply once, when Victor recalls it in chapter one, but twice by way of explaining his mother's origins and marriage to his father. Later, years after his mother's death, Victor returns from his studies at Ingolstadt and describes his entry in his "father's house." Immediately after musing to himself how much he loves his father, he shifts his attention to the portrait of his mother that "stood over the mantelpiece": "It was a historical subject, painted at my father's desire, and represented Caroline Beaufort in an agony of despair, kneeling by the coffin of her dead father. Her garb was rustic and her cheek pale; but there was an air of dignity and beauty that hardly permitted the sentiment of pity" (R 73). This visual representation of the mother's abject weakness, her complete dependence on the largesse of her rescuer, M. Frankenstein, her "rustic" poverty inscribed for all to see, this is the portrait that she had to live with as a continual reminder of her debt to her husband/substitute father. It would appear that it was this portrait that incited Victor's barely suppressed rage against his father throughout the text. The portrait stands as the father's continual semiotic abuse of the mother, a visual monument to her inferior economic and social status, a testament to her identity as a piece of damaged goods rescued through sheer generosity by the magnanimous pater familias.

We last see Caroline in Victor's dream, that November night when the creature first opens his eyes to stare blankly into his creator's eyes. Or rather we see the mother/beloved spiral in Victor's unconscious in a most unpleasant and revealing manner. Initially Victor tells us that he sees Elizabeth "in the bloom of health, walking in the streets of Ingolstadt" (R 53). Her sexual attractiveness and availability are suggested here, but no sooner is that image presented than it is censored by the memory of 
the mother, "as I imprinted the first kiss on her lips, they became livid with the hue of death; her features appeared to change." The oedipal taboo is awakened as Victor kisses Elizabeth only to discover that he is kissing the corpse of his dead mother: "a shroud enveloped her form, and I saw the grave-worms crawling in the folds of the flannel" (R 53). But notice the qualifiers throughout: Elizabeth's features "appear" to change; he "thinks" he is holding his mother. Victor is a victim of his own self-created projections of women. He thinks of Elizabeth as an extension of his mother; indeed, such a connection will later cause Elizabeth's death. But the connection is not simply in Victor's mind. Mary Shelley insinuates that her society has fostered this attitude, has encouraged men to marry miniatures of their mothers and then punish those wives for whatever grievances they still nurse against their mothers.

But if we see Caroline only through the eyes of her husband or his ventriloquist, Victor, then we see Elizabeth the idealized daughter-sisterbeloved initially through Caroline's eyes. Or at least we see a mother seeking for a daughter and finding the perfect one ready-made in little Elizabeth Lavenza, another convenient orphan girl available for purchase. In the revised and later version of the novel, Caroline and her son, the five year old Victor, find themselves one day wandering around the shores of Lake Como only to come upon a peasant family with five hungry children. The one child who bears no resemblance to the others is the prize: "this child was thin and very fair. Her hair was the brightest living gold, and despite the poverty of her clothing, seemed to set a crown of distinction on her head" (R 235). The girl is introduced as a "daughter of a Milanese nobleman" and a "German [who] had died on giving her birth." Yet another motherless cherub, Elizabeth mirrors Caroline's identity, and both of them obviously mirror Mary's sense of herself as "noble," misplaced in the home of the odious Mrs. Clairmont. The gothic as disguised family romance is nowhere more evident than in this vignette. Consider the description of Elizabeth, addressed not once but twice as a deity:

Her brow was clear and ample, her blue eyes cloudless, and her lips and the moulding of her face so expressive of sensibility and sweetness, that none could behold her without looking on her as of a distinct species, a being heaven-sent, and bearing a celestial stamp in all her features. (R 235) 
After the adoption, M. Frankenstein returns home from a business trip and finds his son Victor playing with his new "present," Elizabeth. She is described as a "cherub-a creature who seemed to shed radiance from her looks, and whose form and motions were lighter than the chamois of the hills" (R 235). It is significant that in both patterns of imagery, Elizabeth is everything but human. Initially she is divine, a cherub, a "distinct species." Later she is compared to a chamois, a graceful deer, but an animal nonetheless. The extreme hyperbole followed by denigration (albeit unintended) suggests that the identity and significance of Elizabeth is problematic for the author. Elizabeth is presented to Victor as a sort of spoils of war, a trophy, a prize, an object to "protect, love, and cherish" (R 235). She is the very embodiment of the female body as a fetish, a highly prized erotic substitute. But substitute for what? Is the body of the father or the mother the real object of love and devotion in this text? We can recognize a "negative Oedipal" compulsion throughout Mary's fiction as Veeder notes, an attempt to conceal the fact that the father is the ultimate love object for the central consciousness, and the mother a mere inconvenience and obstacle. But the truth would appear to be actually more complicated. Mary Shelley writes as a man throughout several of her works, not simply to disguise her feminist project, but to conceal her ambivalence toward being a woman herself. This is a woman who inflates and hyperbolizes her descriptions of her female characters as a mode of disguise. This is a woman who fears to name or reveal her true feelings.

Elizabeth as ready-made daughter brings not simply her loveliness and youth to the Frankenstein domicile, she also brings the influenza. In a heroic effort to save her "favorite's" life, Caroline nurses Elizabeth only to contract the disease and die herself. Caroline's carefully staged deathbed scene enacts an oedipal drama that would haunt the dreams of even the hardiest of souls. In her final words, Caroline joins the hands of Victor and his "sister" and insists that they marry because Elizabeth "must supply my place to my younger children" (R 38, 240). She has asked Victor in effect to marry his mother as well as his sister, and his subsequent efforts to complicate and abort that arrangement impel all of his later actions. In creating his own baby, Victor is denying his need for a spouse. In creating his own baby, Victor is both making and rejecting a family for himself. In creating his own baby, Victor is feminizing himself and revealing that the real subject of this text is the anxiety and fear about creating babies. Caroline 
dies not in childbirth, but in nursing a child she brought ready-made into the household. The familial tie is fatal for women, and it is not for men. Later Elizabeth will die on her marriage bed, a sacrifice to Victor's ambivalent sexual desire, just as Justine will die because her beauty attracted the attention of Victor's creature. In each case the woman is destroyed by the very qualities or characteristics that the sentimental genre has propagated and imposed on women. Beauty, weakness, nurturance, and silence-while supposedly valorized by sentimental conventions and mandated as proper behavior for women-actually doom them if they do not also possess those qualities most condemned in women - strength, cunning, deceptiveness, and manipulation. We could conclude that the gothic as practiced by Mary Shelley turned the sentimental ideology on its head and warned women that without those qualities traditionally condemned by male writers, women would doom themselves to a form of self-imposed extinction. To be a sentimental woman was an anachronism, and a potentially fatal one at that. Consider the case of Justine.

Just as gothic melodrama is conventionally constructed around a trial scene-a ritualized vindication of the heroine-so is Frankenstein constructed around a series of trials in which the guilt of Victor is acted out time and time again without revealing his responsibility. ${ }^{4} \mathrm{I}$ intend to examine the first trial-leading to the execution of Justine- as a particularly revealing example of Mary's latent authorial purpose. To sacrifice Justine for the murder of William, Victor's younger brother and rival for the mother's love, reveals Mary's ambivalent use of the female body as a substitute version or inferior model for the primal and much more powerful, unassailable "male" body. It is Victor and his creature who are guilty of the murder of William, but it is Justine who pays the price. Later we see Elizabeth also served up as a sacrificial lamb for Victor's betrayal of the creature's desires, but in both cases it is the bodies of women that are stylized and represented here. The mythological triple female figure-mother, lover, and crone-that recurs throughout the work of the male British romantics, appears in Mary's version with a difference.

Like her mother, Mary inserts the class issue. In presenting an innocent and victimized servant woman who is sacrificed to conceal the corruption of the aristocracy, she continues a tradition begun by her mother. Justine, the major second female victim, is specifically connected 
to Caroline both through her identity as Caroline's particular "favorite," and also through the miniature of Caroline that is placed on her person by the creature to incriminate her. The mark of the mother, a badge of shame and guilt, implicates Justine in her identity as a substitute for the maternal body. If the mother's body is no longer available for abuse, then the nearest and most convenient surrogate for the mother must be employed. The most telling connection between the two, however, is their silence. If Caroline communicated primarily through her tears, so does Justine. She addresses the court just once to plead her own case in a halting and unconvincing performance. The point Mary is making suggests that women have been silenced by their bodies; their female flesh alone indicts them, proves their guilt. There is finally no point in speaking if one will not be heard, if one can never be understood. Caroline speaks as little as Justine throughout the book because finally Victor, the "male" consciousness, could never see or hear either of them as anything other than constructions within his own mind.

Justine is first introduced-rather clumsily-in a letter sent from Elizabeth to Victor. With as heavy an authorial hand as one can imagine, Mary has Elizabeth relate to us Justine's "history," as well as the "occasion [on which she] entered our family." Like Elizabeth, the orphan, and Mary Shelley, Justine was one of a large family of children, but like the fantasy-child that Mary thought herself to be within the Godwin-Clairmont household, Justine was the "favourite of her father." And also like the child Mary's suspicions about her stepmother, Justine's mother "through a strange perversity, could not endure her . . . and treated her very ill" (R 60). Justine, like all the women in this novel, has no real mother. True, she has a living biological mother, which is more than Elizabeth or the young Caroline had, but she does not have a mother's love, and a mother's love would appear for Mary Shelley to be the most important factor in assuring happiness and success in one's life. The devastation caused by a lack of maternal love is repeated again in the heroine of Mary's novella Mathilda's life, but in this earlier novel women are continually forced to stand in relation to each other at precisely this point. Caroline stands to both Justine and Elizabeth as a substitute mother, while later she asks Elizabeth to represent herself to her children as a substitute mother. The wound is located exactly at the place where the mother should be; the wound is inscribed in the mother's absence. 
The class issue, however, is raised in Elizabeth's letter in a way that reminds us of Mary Wollstonecraft's use of the same motif. Elizabeth informs Victor, by way of explaining how another lower-class girl could be brought into the family as yet another quasi-sibling, that "there is less distinction between the several classes of [Geneva's] inhabitants; and the lower orders being neither so poor nor so despised, their manners are more refined and moral. A servant in Geneva does not mean the same thing as a servant in France and England. Justine, thus received in our family, learned the duties of a servant; a condition which, in our fortunate country, does not include the idea of ignorance, and a sacrifice of the dignity of a human being" (R 60). Justine is given an education above her rank by Caroline, who "conceived a great attachment for her," (R 60) and she is also given a gothic heroine's revenge. After the death of her beloved Caroline, all of Justine's siblings die and her mother calls her home to repent of her earlier hardness towards Justine. Like so many other avenging gothic daughters, Justine is able to see her repentant mother punished with death, while at the same time placing in her biological mother's place the memory of her ideal fantasy mother Caroline, whom Justine is now said to resemble. The class issue is brought up and quickly elided because class is an extraneous factor in the portrait of Justine. Like the other heroines of the literary fantasies Mary spun for herself as substitute-formations, Justine is a fairy-tale heroine, a victim of the family romance, a "very clever and gentle and extremely pretty"(R 61) young woman who deserves to be loved, nay worshiped, by everyone who meets her.

Let us examine in some detail the trial of Justine, both as a melodramatic set-piece, and as a tableaux vivant, a moving vignette designed to represent the body of the female as indicted regardless of the evidence or lack of it. We see the scene through our narrator Victor's eyes, who tells us once again that Justine "was a girl of merit and possessed qualities which promised to render her life happy; now all was to be obliterated in an ignominious grave, and I the cause!" (R 77). Like others before me, I am certainly struck by the fact that Victor is removing and punishing his competitors for the dead mother's love one by one. ${ }^{5}$ And in having Justine punished for the murder of William, his younger brother, he manages to kill two birds with one stone. Now recall that it was William's portrait that hung below his mother's in the place of honor in the drawing room, and that it was William who was the particular 
favorite of his mother. Also recall that Caroline had adopted not just one pretty daughter, but two, and that Justine had come into the home as yet another maternal favorite and had taken even more attention away from the ever-needy Victor. But notice how Victor shields himself from responsibility for Justine's execution by claiming that he could not come forward and give evidence because if he told the truth about an eight-foot monster such declarations would be "considered as the ravings of a madman and would not have exculpated her who suffered through me" (R 77). Notice also how Victor is able to say through both the deaths of William and Justine, "a child is being beaten," but at least it is not me, at least my father is not beating (or loving) me.

Dressed in black and led to the slaughter, Justine tries to defend herself by a "plain and simple explanation of the facts"(R 78). She hopes also that her "character" will weigh in her favor, but her naivétè is revealed as she begins to relate her movements on the day of the murder. She cannot imagine how the miniature was placed on her person because, she says, "I believe that I have no enemy on earth, and none surely would have been so wicked as to destroy me wantonly" (R 79). But Justine does have enemies-Victor and his creature. When he could speak as a character witness for her and support the testimony of Elizabeth, Victor instead chooses silence and runs out of the courtroom. He feels only "the horror of my situation," and instead of sympathizing or empathizing with Justine, he muses that the "tortures of the accused did not equal mine; she was sustained by innocence, but the fangs of remorse tore my bosom" ( R 80). Victor would appear to be as solipsistic as any male in the Romantic canon, indeed he very blatantly recalls Percy's portrait of a solipsist in Alastor. When he and Elizabeth visit Justine in her prison cell, awaiting her doom, we hear less about her than about his state of mind: "I, the true murderer, felt the never-dying work alive in my bosom, which allowed of no hope or consolation"(R 84). On the very day of her death, Victor protests that he would like to make some "passionate and indignant appeals" to the judges, but instead his "purposed avowal died away on [his] lips" (R 246).

Choosing not to speak protects his own reputation, but no sooner is Justine dead than Victor shifts his attention to the suffering he has caused his next victims, Elizabeth and his father. True, Clerval is expendable and will also soon be sacrificed to Victor's need to destroy everyone for whom he or his parents have ever felt an affectionate or emotional bond, but 
the rampage was motivated for Victor initially by his horror toward the human family. Assembling a new body, a new life from scraps of old lives represents for Victor the work that occurs in human families, and it is the mother who is the master builder of such assemblages. What Victor does with his scientific experiments is what a mother does within her body, that "filthy workshop" of the womb. But Victor's initial narrative comes to a halt with the first two murders. He confronts his creation and hears from the monster's own mouth his version of the same story. He hears that he has failed miserably as a father, and his new substitute family has existed only to bring into being a force that would exterminate his own family of origins. We learn that Victor has more than a bit in common with William Godwin.

When the monster tells his tale he introduces female characters who mirror and indeed parody the triple-goddess formation that Victor constructed in his own version of the family romance. Where Victor had Elizabeth the monster has Agatha; where Victor had William the monster has Felix; where Victor had Justine the monster has Saphie. Perhaps the most significant substitute-formation, however, is the role of ideal and idealized parent-instructor. Where Victor had Caroline and Alphonse, the monster had only a crippled version of one parent, the blind man DeLacey. Parents-both biological mothers and symbolic fathers-are wounded and ritualistically marked as damaged in this text. The God of Milton's Paradise Lost would appear to stand here as the prototype of a disappointing and arbitrary parent. Like the monster, human beings in Mary Shelley's eyes would appear to be created and flung into a hostile or indifferent universe to battle for their very survival. The dream of a beneficent and all-knowing protector, the frustrated quest to find and embrace such a parent-god, haunts all of Mary Shelley's writings, nowhere perhaps more poignantly than in the monster's narrative, the innermost core of the Chinese boxes.

As a self-created tale mediated by Milton, Plutarch, and Goethe, the monster describes the same sort of bookish childhood possessed by Wollstonecraft's heroines. Taught to measure reality against the idealized portraits depicted in religious, political, and sentimental literature, the monster forms a very unrealistic notion about how the happy Felix and the beauteous Agatha will receive him. Whereas Caroline willingly adopted both Elizabeth and Justine into her bounteous home, DeLacey is not able to extend the same generosity to an eight-foot monster with 
an accent that sounds remarkably similar to his own. The text replays the same tropes-parental duties, sibling rivalry, adoption and education as a form of nurturance-but the monster's version of the family romance can only fail given his unrealistic and literarily-induced expectations. Taught to believe that all men are as sentimental and sensitive as Werther, he is shocked to be kicked by the handsome Felix. Taught to believe that parents create their children out of love, he is distraught to learn that he has been abandoned to his fate. Taught to believe in justice, courage, and fair play, he is unable to understand his complete rejection by the DeLacey enclave. His expulsion is a fall into a postlapsarian world, just as his earlier voyeuristic consumption of the DeLacey domicile was a limited immersion in a prelapsarian world.

The creature's fall is reified in his murder of little William, whom he erroneously believes to be the younger child, the favored son of Victor. The motif here would appear to be the elimination of the sibling-rival as an act of revenge against a parent who has failed to provide adequate love and support. But another way of reading the episode would allow us to consider the creature as a wounded gothic daughter run amok. If Mary depicts herself in veiled terms as the creature, the aborted and rejected product of the union of Godwin and Wollstonecraft, then the creature's "acting out" against both William and Justine reveals the actions of the typical gothic daughter. These young women always manage to remove their rivals, although usually with considerably more subtlety and finesse than the creature uses here. In fact, the crude murder of William is the act of an apprentice gothic daughter. The theft of the miniature and its placement on the body of Justine is the act of a more sophisticated, diabolically cunning one. Of the two murders, Justine's shocks us the most because the motive appears to be simply gratuitous. With William, we can see a causal connection between the baiting of the creature, the flaunting of the father's name and status, and the sudden throttling. Here the crude response is simply to remove one's rival, much in the same way that Jane Eyre later removed Bertha Mason Rochester.

In William's murder we see one strain of the gothic daughter's project, the elimination of the rival heir to the estate. False and diabolical claims are always being made against the rightful estate and inheritance of the gothic heroine. The creature feels, with a fair amount of justification, that he has been created and then abandoned by a father who has set up a rival household with a pretty little boy as his favored and legitimate 
heir. The creature's assault on William is an attack on the patrilineal tradition that has dispossessed one "son" in favor of another. Mary's sense of dispossession in favor of Godwin and Mrs. Clairmont's son, significantly named William, is all too blatant here. As for Justine, consider her as a veiled version of Mary's step-sister, Jane "Claire" Clairmont. Claire not only tagged along on Mary and Percy's elopement and "honeymoon," she was a persistently seductive presence throughout Mary's marriage to Percy. The fantasy of ridding herself of Claire once and for all must surely have crossed Mary's mind more than twice.

In the murder of Justine, however, we see a slightly different configuration of the female gothic project. Justine epitomizes the female rival, the object of desire, the blatant substitute for the mother. Notice that when the creature ponders the miniature of Caroline, he dwells on "her dark eyes, fringed by deep lashes, and her lovely lips”( R 139). The mother's eyes, the first objects in which we recognize ourselves as other than and separate from the mother, are crucial to a sense of identity. And yet these eyes have been denied to the creature, just as they were to Mary Shelley. The mother's lips are a displacement formation for the infant's hungry mouth, the orifice that can never be satisfied because its needs for nourishment, emotional and physical, are infinite. After the creature ponders this miniature for awhile, however, his "rage" returns and he remembers "that I was forever deprived of the delights that such beautiful creatures could bestow; and that she whose resemblance I contemplated would, in regarding me, have changed that air of divine benignity to one expressive of disgust and affright" (R 139).

The creature wants the mother, but knows he cannot have her. When he looks at Justine he sees a version of the mother: "she was young, not indeed so beautiful as her whose portrait I held, but of an agreeable aspect, and blooming in the loveliness of youth and health"(R 140). His perverse response to this innocent embodiment of female fertility suggests a certain spirit of malice and spite. Planting the miniature on her as evidence, he whispers in her sleeping ear: "Awake, fairest, thy lover is near-he who would give his life but to obtain one look of affection from thine eyes: my beloved awake!"( $\mathrm{R}$ 251) The creature wants from Justine the "gaze" that he did not have from his mother. He wants to be mirrored in the mother's eyes and to see himself there as a human being. Earlier when he had looked into a pool of water, he had seen himself as deformed, monstrous, ugly. It is the mother's eyes that will make him 
human, but it is a mirror he will never be able to enjoy. Wanting to punish Justine for her unattainability, he decides that she shall suffer for the crime he committed: "I am forever robbed of all that she could give me, she shall atone. The crime had its source in her; be hers the punishment!" (R 251).

This passage is crucial for understanding the dynamics of passive aggression and the female gothic project. If one cannot have what one wants-whether it be a castle or a title or a particular love object-one can always find a way to get it if one removes one's competitors and blames someone else for the removal. Justine is a convenient scapegoat for William's murder, but her choice as victim is not simply coincidental. Gothic daughters ultimately blame their mothers for failing to be strong enough to protect them from the slings and arrows of the patriarchy. Justine's eyes are the focus of her description because they trope the residue of the mother for the creature's psyche. When he decides to destroy Justine, he immediately decides that he must have a mate made in his image. He concludes his narrative to Victor by stating his command, the point toward which his narrative as argument has tended: "My companion must be of the same species, and have the same defects. This being you must create" (R 140).

Victor's initial attempt to create a female monster has been read as the moment of buried desire in the text, the incident that reveals most clearly Mary's elided gothic feminist project. ${ }^{6}$ As Victor debates the merits of creating another "monster," this time a female one who will accompany her mate into the wilds of South America, he initially agrees to the demand: "I shall deliver into your hands a female who will accompany you in your exile ... (R 144). Exhilarated by the prospects of being once again engaged in his "filthy process," Victor retreats to Scotland (scene of Mary's childhood happinesses in a "normal" family) and constructs his second protégé. This time, however, he does not imagine he is engaged in creating a new race of supermen; he knows that he is creating a monster, and a female one at that. His anxiety about the female is significant for what it reveals about Mary's own ambivalence about being a woman, inhabiting a female body. In thinking about this female creature, Victor can only muse that "she might become ten thousand times more malignant than her mate, and delight, for its own sake, in murder and wretchedness" (R 163). Later, he muses that the female would probably attain consciousness and find the male creature as loathsome as everyone 
else does. Finally, however, he hits on the real source of anxiety, that the female will allow the creature to reproduce and that will lead to a race of monsters preying on the "existence of the whole human race" (R 163).

Reproduction-sexuality and the production of life that generates a cycle of growth and decay-is the central horror, the monstrous heritage at the core of this text. As he assembles the pieces of the female body he sees the "demon at the casement," smiling in anticipation of receiving his bride. Unable to tolerate the idea that his two creations could possibly find happiness without him, enclosed within their own expanding familial unit, Victor suddenly "tore to pieces the thing on which I was engaged. The wretch saw me destroy the creature on whose future existence he depended for happiness, and, with a howl of devilish despair and revenge, withdrew" (R 163-164). Victor does not want there to be any happy families; he does not want to see the physical evidence of sexuality in children, either the creature's or his own. We might read him as the childless Godwin as portrayed by the childhood imagination of his neglected daughter Mary. We might read him as Percy Shelley, unable to accept the responsibilities of either his household with Harriet Westbrook or his second one with Mary. But finally we can read Victor's repugnance for female flesh as Mary's own. This is a woman who punishes all of her female characters in one way or another. This is a woman who understands the gothic project, but rejects it and finally escapes into an apocalyptic denial of the flesh altogether.

When the creature sends his subtle warning to Victor, "I shall be with you on your wedding-night," (R 166) he expresses Mary's own horror at the monstrous heritage implicit in female sexuality and generation. If the creature represents the split-off and active presence of the gothic daughter within the central, more repressed consciousness of Victor, then the wedding night confrontation is actually intended to be read as a struggle between the two sides of Mary: her repulsion and her acquiescence toward adult sexuality. On one hand, Mary is drawn, like Victor with the rejected female creature, to the dream of piling the body into a basket, weighing it with stones, and sinking it in a lake. This image of sinking the female body, burying it, aborting it before it could be born to birth more bodies, is a powerful wish throughout the text. Burying Caroline, then Justine, then the female monster, then Elizabeth-these are the acts that define the consciousness that is "Victor." Traditionally read as a slightly veiled portrait of her husband, 
Victor can also be read as Mary's own fantasized victory over the female body.

In burying so many women, Mary denies her own tie to the female heritage of sentimentality, suffering, victimization, and sexual bondage. In rejecting the histories and identities of Caroline, Justine, and Elizabeth, Mary refuses to endorse any of the appropriate models of female behavior open to women of her class in 1818 . But she also rejects the possibility of being a "monstrous female" by having Victor kill his second creature before her birth. Mary cannot allow Victor and Elizabeth to marry because she cannot imagine the creation of a new family independent from the domicile presided over by the powerful precursor, M. Frankenstein. This novel, like Mathilda is about the child's futile struggle to overthrow and replace the patriarch's power-base, the family of one's origins.

When Elizabeth writes to Victor her final letter before their ill-fated wedding, she asks him if he has not indeed grown colder toward her. She goes on to ask if his indifference is not caused by a dim sense of the incest taboo: "But as brother and sister often entertain a lively affection towards each other without desiring a more intimate union, may not such also be our case? Tell me, dearest Victor. Answer me, I conjure you, by our mutual happiness, with simple truth-Do you not love another?" (R 185). Incest hovers around Frankenstein just as it looms in Percy Shelley's works, particularly Laon and Cythna, Epipsychidion, and Prometheus Unbound. Both writers were conscious of the tremendous attraction and repulsion they felt toward both of their parents and their siblings, and both used that ambivalence to shape the obsessive concern with incest in their works. But Elizabeth dies in Mary's work because Victor is in love with someone else-himself writ large as his own creation. Victor loves his creature as he loves himself - that is, Victor and the "monster" are two sides of the dilemma of being female in a male-dominated society. "Victor" would appear to be the socially-constructed "woman" who cultivates her reason, who educates herself to the very best of her ability, who is motivated by the best of intentions. "Victor" is the "woman" who manages to reproduce without sullying her flesh or exposing herself to the ravages of generation. "Victor" is, it would appear, exactly the sort of "woman" Mary Wollstonecraft advised her contemporaries to become-reasonable, calm, above the realm of emotional and irrational passions. And yet, "Victor" is a failure, a sham, a miserable force of unnatural destruction. 
But if "Victor" is a critique of the heritage of Wollstonecraft, what is the creature? Emotional, needy, devious, manipulative, desperate, murderous, increasingly insane and violent, the creature would appear to be the woman who has discovered that reason and education do not lead to the promised land. The creature is a version of the gothic daughter, canny and vengeful, spiteful and envious. When the creature destroys William and Clerval, "he" is removing male rivals for the estate. But when "he" is dispatching Justine, and then Elizabeth, "he" is rejecting and destroying those models of female behavior that have been proffered as acceptable by "his" society. He is, in other words, acting out Mary Shelley's refusal to be a passive servant or a compliant wife. When Victor leaves his bride on their wedding night to prowl around the hallways, he tells us that he has done so because he has suddenly realized "how dreadful the combat which I momentarily expected would be to my wife" (R 192). Of course, we are supposed to think that Victor's anxiety is caused by anticipating that Elizabeth will be merely a passive witness to his "combat" with the creature. The "combat" that Victor fears is actually with Elizabeth, on the marriage bed. Victor would much rather be roaming around the hallways looking for his Doppelgänger than protecting his bride. The scene in which she is murdered is a classic statement of sexual displacement:

She was there, lifeless and inanimate, thrown across the bed, her head hanging down, and her pale and distorted features half covered by her hair. Everywhere I turn I see the same figure-her bloodless arms and relaxed form flung by the murderer on its bridal bier. ( $R$ 193)

Fuseli's painting "The Nightmare" was the visual source for the scene, and it is surely no coincidence that Wollstonecraft had experienced her own nightmare courtship of Fuseli, complete with rejection by him via his wife's visit with the unpleasant news that no, Mary could not share her husband. Mary Shelley encodes not only her mother and her mother's loves and death in this moment of the text, she also buries her own worst fears about sexuality, marriage, and motherhood as death for women. Just as Elizabeth turned into Victor's dead mother in the earlier dream, so now do the mother and the beloved spiral into each other. Elizabeth as "bloodless" is a repudiation of what Mary knows the sexual woman is: bloody. The words "pale" and "distorted" remind us of the night that the 
creature first opened his eyes. Elizabeth has been as much a creation of Victor as his monster was. The combat on the wedding night is finally between the two sides of Mary Shelley that could not come to terms with the death implicit in sexuality and generation. When the creation of Victor kills Elizabeth, we have an acting out of the emotional child against the feminine ideal, a lashing out, a rejection and repudiation that denies and at the same time destroys the beloved/mother construction. When Victor rushes to hold the dying Elizabeth for the first and last time, he notices that the "mark of the fiend's grasp was on her neck" (R 93). Just as Justine had been "marked" with the mother's portrait, so is Elizabeth marked with hand prints that signify the grip of the physical and material on her body. Elizabeth is doomed because she is an embodiment of the female flesh and all the corruption, all the blood that it is capable of producing.

The final point to be made about the identity of Elizabeth can be found in the revisions of Frankenstein. The change in the identity of Elizabeth Lavenza concerns her transformation from a cousin in the first version to an orphan-foundling in the revised and much later version. The change in Elizabeth's identity, from an insider within the family to an outsider, mirrors the cultural shift that Foucault has identified as occurring in this period. This shift required that marriage become an exogamous institution, an alliance not with members of one's own kinship group, but with outsiders, people clearly recognized as not belonging in any way to one's family of origin. ${ }^{8}$ The trauma of changing marital arrangements, of marrying outside the clan, recurs throughout gothic and sentimental fiction, from Smith's Emmeline to Bronte's Villette. Initially, one is tempted to read the impetus to stay within the family as a basically incestuous lure, a desire to merge with those we see as the "same" rather than as those we see as "other." The incestuous subtexts of Wuthering Heights and Jane Eyre have traditionally been read on just this level. But all of those works, as well as Frankenstein, can also be read as extended social and political allegories, suggesting new class formations as well as promising a reformed political structure based not on privilege but on merit.

But to what sort of merit system does Mary Shelley subscribe? She has rejected reason in her portrait of Victor. She has rejected education in her portrait of the creature's pedagogical project. She has rejected faithful service and familial devotion in her portraits of Justine, Caroline, and 
Elizabeth. A shocking nihilism begins to emerge in this text, muted it would appear only by the artificial presence of Mrs. Saville and her navigator brother in the final narrative of the chinese box. Critics have contended that Mrs. Margaret Saville represents normative bourgeois culture-the reification of the domestic, the safety and conformity one finds in a supportive community of other like-minded fellows. But surely it is significant that the final narrative, Walton's, is written by a brother to his sister. Once again the incestuous pull is greater than even he can consciously acknowledge. When Walton thinks about what misery his own death at sea would cause his sister, he muses, "But you have a husband and lovely children; you may be happy. Heaven bless you and make you so" (R 214). To be driven out of one's family of origins would appear to be the crime, the fall in this text. To be forsaken by his sister for another man and then other children, this is the wound that Walton's wanderings cannot erase. Like Victor and the creature, Walton ("walled-town") cannot reach out to others to create a new family. He can only cling desperately to the shards of his original family, his married sister.

Frankenstein concludes in a blaze of fire and ice, a destructive blood-letting that suggests that when the erotic turns on itself and can find no outlet to produce it can only consume. Alphonse Frankenstein, the Alpha of Victor's universe, dies of grief. Victor expires in Walton's arms, condemning his own ambition, and cautioning Walton to "seek happiness in tranquility" (R 215). The final victim, the creature, claims Victor as his trophy: "In his murder my crimes are consummated; the miserable series of my being is wound to its close . . . what does it avail that I now ask thee to pardon me? I, who irretrievably destroyed thee by destroying all thou lovedst. Alas! he is cold; he may not answer me" (R 217). But Victor has always been "cold," and we emphasize the word with the awareness that Percy Shelley would later describe his beloved wife Mary as a "cold chaste moon" in Epipsychidion. The horrendous series of murders in this novel is shocking because they suggest what few writers have ever been willing to pen-that our deadliest enemies in life are those living under our same roof. In creating a creature who acted out his master's unexpressed wishes, Victor became the alter-ego of Mary Shelley, the ambivalent feminist, the estranged daughter, the illicit mistress and unlucky young mother.

And so in reading Victor we are compelled to conclude that "he" is also on some level a slightly veiled version of the son that Mary Shelley 
imagined she would have been to Godwin. Wollstonecraft was convinced when she was pregnant with Mary that she was carrying a boy, and she and Godwin playfully addressed the impending child as "William." Mary Shelley's consciousness of disappointing her father was clearly intense, for not only was she not the promised son and heir, she killed her mother in the process of coming to life. This guilt-the wound and trauma that was her very existence-is writ large in the creature's gigantic status and his intense and freakish ugliness. To split oneself into two figures - the reasonable and educated Victor and the rejected and emotionally damaged creature-was an act of literary genius and emotional daring. It was also, however, the act of a wounded psyche.

\section{Notes}

1. One of the most provocative recent examples of a critically polymorphous reading of Frankenstein can be found in Chris Baldick's In Frankenstein's Shadow: Myth. Monstrosity, and Nineteenth-Century Writing (Oxford: Oxford UP, 1987). I consider Franco Moretti's "Dialectic of Fear" in his Signs Taken for Wonder, Essays in the Sociology of Literary Forms p. 83-108 (London: Verso, 1983), 830108; to be the most interesting Marxist reading of Frankenstein and Dracula as the two sides of the capitalistic nightmare. A valuable overview of Marxist, feminist, psychoanalytic, reader-response and cultural readings of the novel can be found in the "Frankenstein: Case Studies" in Contemporary Criticism, ed. Johanna M. Smith (Boston: St. Martin's Press, 1992).

2. My use of the symbolic meaning of the names in the novels is drawn from William Veeder's Mary Shelley and Frankenstein: The Fate of Androgyny (Chicago: U of Chicago P, 1986), while Percy Shelley's influence on her novel is explored in E. B. Murray's "Shelley's Contribution to Mary's Frankenstein," Keats-Shelley Memorial Bulletin 29 (1978), 50-68. I admire immensely the biographical reading of Frankenstein found in Veeder's study, and on the same subject, also see John Dussinger, "Kinship and Guilt in Mary Shelley's Frankenstein," Studies in the Novel 8 (1976), 38-55; J. M. Hill, "Frankenstein and the Physiognomy of Desire," American Imago 32 (1975), 335-58; Gordon D. Hirsch, "The Monster Was a Lady: On the Psychology of Mary Shelley's Frankenstein," Hartford Studies in Literature 7 (1978), 116-53; Joseph Kestner, "Narcissism as Symptom and Structure: The Case of Mary Shelley's Frankenstein," in The Nature of Identity (Tulsa: U of Tulsa P, 1981); Laura Claridge, "Parent-Child Tensions in Frankenstein: The Search for Communion," Studies in the Novel 17 (1985), 14-26; and Peter Brooks, "What is a Monster? According to Frankenstein " in his Body Work: Objects of Desire in Modern Narrative (Cambridge: Harvard UP, 1993).

3. I discuss both the earliest and the later (1831) revised texts of Frankenstein, but all quotations will be from the 1818 text and its variants and will be taken from the version edited by James Rieger (Indianapolis: Bobbs-Merrill, 1974; rpt. Chicago: U of Chicago $P, 1982)$. The 1831 version amplifies Victor's childhood, provides more and different 
information about Elizabeth and Clerval, and gives greater detail about the death of Justine. All quotations from the text will be from the 1818 text edited by James Rieger and will be cited parenthetically as $\mathrm{R}$.

4. See Peter Brooks, The Melodramatic Imagination (New Haven: Yale, 1976) for a discussion of the trial as a central element in the essentially "Manichean" structure of melodrama. In the struggle between good and evil, melodrama requires a "drama of recognition" that culminates in a "full-fledged trial of the slandered melodramatic heroine, the embodiment of victimized innocence under persecution; her dilemma dramatizes a nightmare struggle for recognition of the sign of innocence, which is also the struggle for the assertion of selfhood" $(27 ; 31 ; 52)$.

5. Modem literary criticism of Frankenstein begins, in my opinion, with Harold Bloom's brief article "Frankenstein, or the New Prometheus," in Partisan Review 32 (1965), 611-18. Feminist approaches to the novel begin with Ellen Moers, Literary Women (New York: Anchor, 1977), while criticism of the novel comes of age with the publication of the G. Levine and U. C. Knoepflmacher collection specifically, The Endurance of Frankenstein: Essays on Mary Shelly's Novel (Berkley: U of California P, 1979). Once a stepchild of literary history, Frankenstein is now as examined as any of the other canonical texts in the British literary tradition.

6. I am alluding to the argument developed by Mary Jacobus in her "Is There a Woman in This Text?," New Literary History 14 (1982), 117-41. The other major feminist and psychoanalytic approaches to the novel can be found in Barbara Johnson in her "My Monster/My Self," Diacritics 12 (Summer 1982), 2-10; Margaret Homans, "Bearing Demons: Frankenstein's Circumvention of the Maternal," in Bearing the Word: Language and Female Experience in Nineteenth-Century Women's Writing (Chicago: U of Chicago P, 1986); Mary Poovey, "My Hideous Progeny: Mary Shelley and the Feminization of Romanticism," PMLA 95 (1980), 332-47; rpt. The Proper Lady and the Woman Writer (Chicago: U of Chicago P, 1983); Devon Hodges, "Frankenstein and the Feminine Subversion of the Novel," Tulsa Studies in Women's Literature 2 (1983), 155-64; and Barbara Waxman, "Victor Frankenstein's Romantic Fate: The Tragedy of the Promethean Overreacher as Woman," Papers in Language and Literature 23 (1987), 14-26.

7. On Mary Shelley's knowledge of Fuseli's painting "The Nightmare" and her awareness of her mother's aborted relationship with Fuseli, see Anne K. Mellor, "Possessing Nature: The Female in Frankenstein," in Romanticism and Feminism, ed. Mellor (Bloomington: Indiana UP, 1988), 220-32; and Susan Wolstenholme, "The Woman on the Bed," in her Gothic (Re)Visions: Writing Women as Readers (Albany: State U of New York P, 1993), 37-56. Analyzing fathers and mothers in Mary Shelley's fiction has been a persistent focus in the literary criticism of her work. A useful overview of the critical history on this topic can be found in Jane Blumberg, Mary Shelley's Early Novels: "This Child of Imagination and Misery" (Iowa City: U of Iowa P, 1993); also see Marc A. Rubenstein, "My Accursed Origin": The Search for the Mother in Frankenstein," Studies in Romanticism 15 (1976), 165-94; James B. Carson, "Bringing the Author Forward: Frankenstein through Mary Shelley's Letters," Criticism 30 (1988), 431-53; and Kate Ellis, "Mary Shelley's Embattled Garden," in The Contested Castle: Gothic Novels and the Subversion of Domestic Ideology (Urbana: U of Illinois P, 1989), 181-206. The 
relationship, real and imagined, between Mary Shelley and her dead mother and flawed father is explored most revealingly in William St. Clair's The Godwins and the Shelleys: The Biography of a Family (New York: Norton, 1989). Gilbert and Gubar's Madwoman in the Attic: The Woman Writer and the Nineteenth-Century Literary Imagination (New Haven: Yale UP, 1979) discusses Mary's relationship with her mother and its influence on her works (213-47), as does Janet M. Todd, "Frankenstein's Daughter: Mary Shelley and Mary Wollstonecraft," Women and Literature 4 (1976), 18-27. On the influence of Godwin on her works, see Katherine Powers, The Influence of William Godwin on the Novels of Mary Shelly (New York: Arno, 1980), and on Mary's relationship with her father, see U. C. Knoepflmacher, "Thoughts on the Aggression of Daughters," in The Endurance of Frankenstein, ed. George Levine and U. C. Knoepflmacher (Berkeley: U of California P, 1979), 88-119. Several recent biographies of Mary Shelley explore the parental influence on her writings. In particular, see Anne K. Mellor, Mary Shelley: Her Life, Her Fiction, Her Monsters (London: Routledge, 1988); Emily Sunstein, Mary Shelley: Romance and Reality (Boston: Little, Brown, 1989); Muriel Spark, Mary Shelley (London: Constable, 1988).

8. See Foucault, The History of Sexuality: Volume 1: An Introduction, trans. Robert Hurley (New York: Vintage, 1980), pp. 148 passim. 